BICCA, Luiz. "Vida Cotidiana e Pensamento Ecológico".

Rio de Janeiro: Ed. PUC-Rio: 7 Letras, 2018.

\title{
Sképsis sobre a natureza em crise
}

Dnda. Maria Helena Silva Soares - PPGFIL UERJ

helenastraub@gmail.com

Recebido em: 19/05/2020

Aceito em: 23/05/2020
Luiz Eduardo de Oliveira Bicca (1951) nasceu no Rio de Janeiro se graduou em Filosofia pela Pontifícia Universidade Católica do Rio de Janeiro em 1976, defendeu seu mestrado em filosofia pela mesma universidade em 1978 e se doutorou em Filosofia pela Universität Tübingen em 1984. Hoje, é professor da Uerj, onde leciona as disciplinas de Filosofia da Natureza e Seminário, a partir do ceticismo antigo e moderno, dentre outros clássicos da Filosofia ${ }^{1}$. Bicca é autor de obras como Racionalidade Moderna e Subjetividade (1997) e Questões Persistentes (2003); e, como professor, inspira uma geração de filósofos formados pela Uerj, UFRJ e PUC-Rio. Seu trabalho em sala de aula é digno de nota por conciliar a erudição com os problemas da vida comum. Assim como o livro que nos propomos resenhar, seu exercício didático associa a análise do tempo presente, da vida cotidiana, ao pensamento abstrato. Tal disposição explicita um acordo entre seus ceticismo e ironia, que se afirmam pela recusa à submissão e à servidão a regras que não atentem para com princípios de cuidado e justiça social. Em suas palavras: "uma defesa da vida ético-política plural, em oposição à tradicional concepção unitária ou unicista da vida política, centrada na obediência automática" (BICCA, 2018, p.14).

Vida cotidiana e pensamento ecológico foi publicado em 2018 e apresenta provocações importantes para entendermos o momento

1 Esta resenha é um reconhecimento ao professor Luiz Bicca, por sua dedicação à pesquisa e ao ensino na Universidade que mais sofre com o capitalismo e a política neoliberal, a Pública. Esperamos, com o presente texto, formalizar um convite à leitura de sua mais recente obra, e empreender a partir dela uma análise do momento presente - como faremos no próximo número da Revista Em Construção: arquivos de epistemologia histórica e estudos de ciência, com um dossiê sobre a pandemia. Optamos por extrapolar o texto ao relacioná-lo com a atual crise, portanto, qualquer imprecisão ou excesso na interpretação é de nossa responsabilidade. 
que passamos com a COVID-19. O isolamento social - provocado pela alta capacidade de transmissão do vírus - e as mais de dezessete mil $^{2}$ vidas perdidas - invisibilizadas por uma política negacionista e totalitária do governo federal e pela chantagem de empresários, assegurados pela política econômica neoliberal do Ministério da Economia -, não constam nesse livro, mas ele apresenta boas referências sobre a origem disto que já é considerado o ponto zero do século XXI, por ser não apenas uma crise sanitária, mas também social e ético-política. O livro se divide em cinco ensaios nos quais somos convidados a pensar temas importantes e atuais tanto a partir do cânone reconhecido pela história da filosofia, quanto por uma bibliografia feita por grupos dedicados à crítica ao modelo de pensar instituído pela tradição.

No primeiro ensaio, Modernidade circundante, o autor destaca que o projeto moderno iluminista, que preconizava o esclarecimento; a revolução industrial, que exaltava a dominação da natureza; e o conformismo da modernidade tardia como fatores que levaram a humanidade a uma alienação de si e dos outros, a sua massificação. Vivíamos, mesmo antes do isolamento social recomendado pela crise sanitária, como "náufragos da existência" incapazes de pensar a nós mesmos e ao outro como partes de um todo, que é a própria natureza. Contra o conformismo político e a soberania do ego, o autor referencia filósofos como Wittgenstein, Emerson, Heidegger, Thoreau, Adorno, Hegel, Marx, Arendt, Freud, Derrida, Lévinas e o ceticismo pirrônico para pensar desde a importância da linguagem na produção de si, de sentido com e para o sujeito, até como a depressão e a ansiedade foram naturalizadas na modernidade tardia.

A modernidade tardia parece estar estendendo o prazo de validade da expressão "tempos sombrios", de que nos fala Hannah Arendt, já que vivemos em um tempo em que nos encontramos diante de forças terríveis que não conseguimos muito bem compreender, muito menos dominar, controlar - forças que nos aterrorizam e nos dão toda uma consciência de impotência em relação a elas. A obscuridade sinaliza não somente perigo, mas ausência de clareza, de esclarecimento, em que grande parte da ameaça provém justamente dessa falta de luz. Estamos desorientados, tropeçando no escuro. Afinal, nosso tempo, como observa um contemporâneo, parece cultivar a mentira e a ignorância (BICCA, 2018, p. 19).

A linguagem, como vemos no primeiro ensaio, é instauradora da comunidade moderna, mas também seu algoz por ser o meio pelo qual se naturalizam identidades e o apagamento da diferença em direção a uma falsa neutralidade, a uma violência do universal. Bicca inspira, ainda que não faça uso desses termos, a reflexão sobre o modo pelo qual o pensamento ocidental moderno forjou o epistemicídio ${ }^{3}$, isto é, o apagamento de saberes acadêmicos ou não, contemporâneos e ancestrais, que hoje resistem, sobretudo, aqui, no Sul global ${ }^{4}$.

No segundo ensaio, Ética e vida cotidiana, ele argumenta que tanto a ética, em seu sentido prático, como a vida comum devem ser analisadas em sua estrita relação entre linguagem e historicidade. Ambas se constituem a partir de valores que são usados, frequentemente, como reprodutores de ideologias e políticas de saber e poder. Ou seja, historicamente, podemos observar um certo conformismo em modelos filosóficos morais e em discursos reproduzidos no senso comum, que tem por fim a perpetuação de um status quo, de modos de vida, pensamentos e comportamentos repetidos habitualmente que são, por isso, naturalizados. Contra a isto o autor afirma:

Defende-se aqui um pensamento moral mais cético e menos ambicioso, porém mais realista, social e psicologicamente. Entende-se que não há teoria ética capaz de fornecer uma fundamentação absolutamente necessária e universal para a moralidade. Na deliberação moral, a primeira pessoa impera, não é substituível por nenhuma outra nem por outra

2 Este número teve de ser atualizado a cada dia em que a autora tentava pôr fim ao texto. Hoje, dezenove de maio de 2020, o Brasil atingiu a triste marca de mais de dezessete mil vidas perdidas e 265.896 casos confirmados. A realidade, todavia, absorve de forma irredutível o que escapa à ignorância e à subnotificação.

3 Ver: CARNEIRO, Aparecida Sueli; FISCHMANN, Roseli. A construção do outro como não-ser como fundamento do ser. 2005. Universidade de São Paulo, São Paulo, 2005.

4 Ver: SANTOS, Boaventura; MENESES, Paula (orgs.). 1. ed. Epistemologias do Sul. São Paulo: Cortez, 2010. 
coisa. No domínio da ética, temos de partir do que somos, não somente do "animal racional”, o que já é uma mutilação, e também na medida em que somos criaturas particulares de uma cultura específica (BICCA, 2018, p.92)

Em Literatura moral, ironia e ceticismo, seu terceiro ensaio, Bicca expõe o ceticismo moderno como um modo de ser, uma disposição afetiva ou estado de insatisfação que parte da decepção do sujeito com a sua condição elementar: a ignorância. A relação entre ironia e ceticismo pode ser, neste sentido, aproximada na história da filosofia seja com Sócrates, seja com Kierkegaard - que via a ironia como uma forma de conduzir-se na existência, na negação da suposta certeza acerca da natureza humana ser inerente ao nascimento. A afirmação da vida como um desenvolvimento marcadamente histórico é o oposto da literatura judicativa que afirma princípios morais como cláusulas pétreas da vida comum, que extrapolam juízos morais enquanto saberes necessários.

Cabe aqui mais uma ponte entre a obra e a crise que vivenciamos, pois nela o autor reflete sobre a exploração da força de trabalho de seres humanos e não humanos, a partir de Donna Haraway ${ }^{5}$, como também aponta para o cinismo presente em uma política de tolerância. Esses pontos constituem, para nós, o principal problema político que ataca nossa já frágil democracia. Seres humanos subalternizados e hierarquizados quanto sua raça, gênero, classe social, território, dentre outros marcadores, e seres não humanos, tomados na totalidade como objetos e força produtiva não remunerada. A tolerância, do autodeclarado superior, permite, ao tolerado, viver e deixar morrer, conforme seus próprios interesses. Ou como bem resume a citação de Terry Eagleton,

Por ter sido redefinida como puramente calculista e pragmática, a política tornou-se agora
o oposto do ético. Mas, como não chegava a ser descarada o bastante para sacudir fora
toda a ética, a política teve que ser conduzida em nome de certos valores morais que, ao
mesmo tempo, ela não tinha como não violar. [...] É por isso que talvez estejamos teste-
munhando a aurora de uma época, pós-ética, na qual os poderes mundiais não mais se
preocupam em cobrir seus óbvios interesses próprios com uma linguagem enganosamen-
te altruísta, mas, ao invés disso, são insolentemente francos a respeito (Terry Eagleton,
Apud: BICCA, 2018, p.121).

O quarto ensaio tem por título Desobediência e parte do perfeccionismo moral de Emerson e Thoreau, dentre outros, não como uma teoria una, mas como uma experiência de transformação de si e da sociedade, de um reencontro com a natureza, como um todo, mas também a humana das quais estaríamos, ou estamos, alienados. O perfeccionismo, em resumo, não pressupõe um único modelo de transformação, mas a necessidade de uma pluralidade, que se viabiliza pelo respeito a si, pela autoconfiança, e ao outro, pela amizade, philia. Ou seja, o dissenso e a alteridade, enquanto práticas de respeito e reconhecimento, são necessários para o fortalecimento das instituições democráticas. O entrelaçamento entre perfeccionismo moral e desobediência civil constitui ponto marcante da filosofia política aqui expressa que afirma: "a desobediência é uma forma de resistência no sentido de eu considerar que não dei meu consentimento, pois, em verdade, meu consentimento não foi dado a toda e qualquer coisa, de uma vez por todas" (BICCA, 2018, p.148).

$\mathrm{O}$ autor alerta que desobediência não pode ser confundida com atos impensados ou violentos. Fica fácil entender a relação de oposição quando pensamos que, em termos políticos, a violência se origina de uma decisão, prática, decreto ou lei injusta e que, por isso - mais radical que a indicação de um direito à desobediência do liberalismo moderno de Locke -, como afirma Thoreau, temos a obrigação de desobedecer (BICCA, 2018, p.154).

5 Ver também: HARAWAY, D. “Saberes localizados: a questão da ciência para o feminismo e o privilégio da perspectiva parcial”, Cadernos Pagu, (5), 1995, p.07-42. 
O último ensaio, Pensamento ecológico, apresenta a complexidade inerente aos problemas ambientais, justificada pelo seu caráter holístico que implica um olhar interseccional ${ }^{6}$, além da diversidade disciplinar. Desde a ecologia profunda, passando pelo reformismo ambiental, a teoria crítica, a crítica marxista, ecossocialista e ecofeminista, Bicca percorre as diversas correntes do pensamento ecológico com o intuito de perscrutar como a cultura ocidental chegou a esse lugar de profunda crise com o ambiente que a constitui. "Nossos ancestrais não podiam prever os efeitos ecológicos de seus atos, mas podemos, com razoável margem de segurança, antecipar efeitos de nossas decisões, nossas atitudes e nossas políticas” (BICCA, 2018, p.177). A separação entre natureza e cultura, sua fetichização e alienação, é ponto comum entre os que se dedicam ao problema. Qualquer mudança significativa, nesse sentido, não passa pela defesa de um capitalismo verde ou políticas de sustentabilidade com foco no consumo, isto é, não devemos nos contentar com um projeto ecológico mitigado que opera pela preservação daquilo que nos trouxe até aqui: o capitalismo.

Contra o humanismo metafísico e a colonização da natureza, a presente obra contorna a perspectiva iluminista e anthropos centrista, a partir de autoras como Isabelle Stengers, Haraway e outras ecofeministas que direcionam seus escritos para a crítica ao capitalismo. Ou seja, é o próprio sistema econômico e social que promove um descompromisso ético e político em relação às consequências dos efeitos danosos de sua política ao ignorar a degradação ambiental e as injustiças sociais e epistêmicas. A ciência, longe da ilusão da neutralidade que lhe é conferida pela modernidade, não está isenta de contribuir para o fortalecimento de políticas negacionistas, tal como aparece na crítica de Latour: "não existe cura para o pertencimento ao mundo" (Bruno Latour Apud: BICCA, 2018, p.258). A questão que permanece cada vez mais atual: como garantir, como direito fundamental, um ar respirável para todos?7

Tal como os alunos da Uerj da turma de 2008 puderam ouvir em seus cursos, Bicca afirma em Vida cotidiana e pensamento ecológico, dez anos depois, a necessidade de não reproduzirmos o pensamento dogmático, burocrático e tecnocrático, que se distancia da vida cotidiana a fim de se autointitular proprietário e gestor da Natureza, seja ela não-humana ou humana. Há em seu pensamento uma crítica à ideia de política como ambiente de privilegiados que representariam a vontade de uma massa homogênea. A política precisa ser o campo das ideias e das ações em disputa, não do conformismo ou da barbárie. A polêmica não pode, todavia, nos paralisar ou impedir o debate com o outro. Complementar ao ceticismo como prática de vida, como proposto pelo autor, entendemos que a objetividade forte ${ }^{8}$, que defende Sandra Harding, constitui uma prática metodológica que inclui outros saberes que não apenas os considerados hegemônicos, estabelecidos pela lógica do capital.

Por isso, discordamos do autor quando ele defende que o voto não deva ser obrigatório. Longe de se tratar de um modelo tirânico, e à luz de um recorte de gênero, raça e classe, entendemos que, com o governo atual, qualquer ataque ao sistema eleitoral pode significar uma perda irreparável à democracia, sobretudo, para aqueles que tiveram apenas há poucos anos seu direito de participação reconhecido, como mulheres, negros e todos aqueles que, por virem de uma classe socialmente prejudicada, não tiveram acesso à alfabetização. O que nos leva a afirmar tanto a partir da leitura de Vida cotidiana e pensamento ecológico quanto do ambiente acadêmico e das disputas políticas acerca da natureza - pensada aqui como uma rede simbiótica entre mundo e seres vivos humanos e não humanos - que não haverá revolução que não passe por uma correlação de forças responsável entre os mais diversos atores que compõem essa rede em crise em que estamos e, ao mesmo tempo, somos, a natureza.

6 Com recorte de gênero, raça, classe, território, dentre outras categorias de análise.

7 "Antes deste vírus, a humanidade já estava ameaçada de asfixia. Se houver guerra, portanto, ela não será contra um vírus em particular, mas contra tudo o que condena a maior parte da humanidade à cessação prematura da respiração, tudo o que ataca sobretudo as vias respiratórias, tudo que, durante a longa duração do capitalismo, terá reservado a segmentos de populações ou raças inteiras, submetidas a uma respiração difícil e ofegante, uma vida penosa. Para escapar disso, contudo, é preciso compreender a respiração para além de seus aspectos puramente biológicos, como algo que é comum a nós e que, por definição, escapa a todo cálculo. Estamos falando, portanto, de um direito universal à respiração". MBEMBE, Achille. O direito universal à respiração, n-1, 2020. Disponível em: https://n-1edicoes.org/020 acesso em: 19/05/2020.

8 Ver: HARDING, Sandra. Objetividade mais forte para ciências exercidas a partir de baixo de Sandra Harding. Revista Em Construção: arquivos de epistemologia histórica e estudos de ciência, número $5 \backslash 2019$. págs. 143 - 162. 